\title{
Particulate Organic Matter Transport to the Deep Sea by Salp Fecal Pellets
}

\author{
K. Iseki* \\ Laboratory of Oceanography, Faculty of Agriculture, Tohoku University, Sendai, 980 Japan
}

\begin{abstract}
Free-floating sediment traps were suspended at 200 and $900 \mathrm{~m}$ in the northern North Pacific Ocean during 20-21 May, 1974. A considerable amount of large, dark-green particles, larger than $1 \mathrm{~mm}$ in diameter, was collected at both depths. These large particles corresponded morphologically with fecal pellets of salps. Vertical carbon flux was estimated to be 10.5 and $6.7 \mathrm{mg} \mathrm{C} \mathrm{m}^{-2} \mathrm{~d}^{-1}$ at 200 and $900 \mathrm{~m}$, respectively. This suggests that vertical transport of salp fecal pellets could play an important role in meeting the energy requirements of bathypelagic organisms in the open ocean.
\end{abstract}

\section{INTRODUCTION}

Recent evidence has suggested that the organic carbon flux to the deep sea is associated with the rapid settling out of relatively rare, large particles - such as fecal pellets and fecal matter (McCave, 1975; Bishop et al., 1977). The sediment trap is a new method for direct evaluation of the vertical mass transport involving various elements in the sea (Wiebe et al., 1976; Iseki, 1977; Honjo, 1978; Iseki, 1981). Most workers have paid attention mainly to fecal-pellet deposition of copepods and euphausiids, because these are numerically often dominant in pelagic waters; however, also pelagic tunicates occur frequently in large numbers in the ocean. This paper shows that salps are equally important.

At certain times salps form huge shools and dominate in plankton tows (Berner, 1967; Brattström, 1972; Wiebe et al., 1979). Berner (1967) reported that a single swarm of the salp Thalia democratica was found with an average density of 275 individuals $\mathrm{m}^{-3}$ in the upper $70 \mathrm{~m}$ of the water column off the coast of Southern California (Madin, 1974).

The feeding of salps differs from that of copepods in the following ways: (1) the food materials ingested range in size from about $1 \mu \mathrm{m}$ to about $1 \mathrm{~mm}$ (Madin, 1974; Harbison and Gilmer, 1976); (2) the particles are retained with a high efficiency down to a size of about $2 \mu \mathrm{m}$ (Harbison and Gilmer, 1976; Harbison and

\footnotetext{
- Present address: Seakem Oceanography Ltd, 9817 West Saanich Road, Sidney, British Columbia, V8L 3S1 Canada
}

McAlister, 1979); (3) the filtering rates range up to tens of $1 \mathrm{~h}^{-1}$ individual ${ }^{-1}$ (Harbison and Gilmer, 1976). Hence, the production of fecal pellets by salp swarms can have an important trophic impact on the deep-sea ecosystem (Wiebe et al., 1979). Our experiments provide the first direct evidence that fecal pellets of salps play an important role in the vertical flux of organic matter in the ocean.

\section{MATERIALS AND METHODS}

The sediment trap used was constructed of paired polyethylene funnels, $90 \mathrm{~cm}$ high and $56.8 \mathrm{~cm}$ across the mouth $\left(0.25 \mathrm{~m}^{2}\right)$. A small glass bottle $(55 \mathrm{ml}$ capacity) was attached to the stem of the funnel. To each bottle $20 \mathrm{ml}$ of formalin solution was added, thus preventing in situ decomposition of sedimented matter however, in order to assess the effect of preservation, formalin was not added to one bottle (200-m sample). Holes were drilled into the sides of the funnels and covered with $67 \mu \mathrm{m}$ Nitex netting; the holes allowed the water to escape after trap recovery. The traps were suspended at 200 and $900 \mathrm{~m}$ depths (Fig. 1), for $29 \mathrm{~h}$ (08:13 May 20 to 13:10 May 21, 1974), at St. 13 in the northern North Pacific Ocean on the KH-74-2 Cruise of R.V. 'Hakuho-Maru' (Fig. 2).

Immediately after trap recovery, the samples were gently transferred into Petri dishes and photographed. Following gentle mixing, the samples were divided into several aliquots for dry-weight measurements, particulate organic carbon (POC) determinations and 
visual observations with light microscope. For dryweight measurements, an aliquot was filtered through an HA Millipore filter and rinsed with a $3 \%$

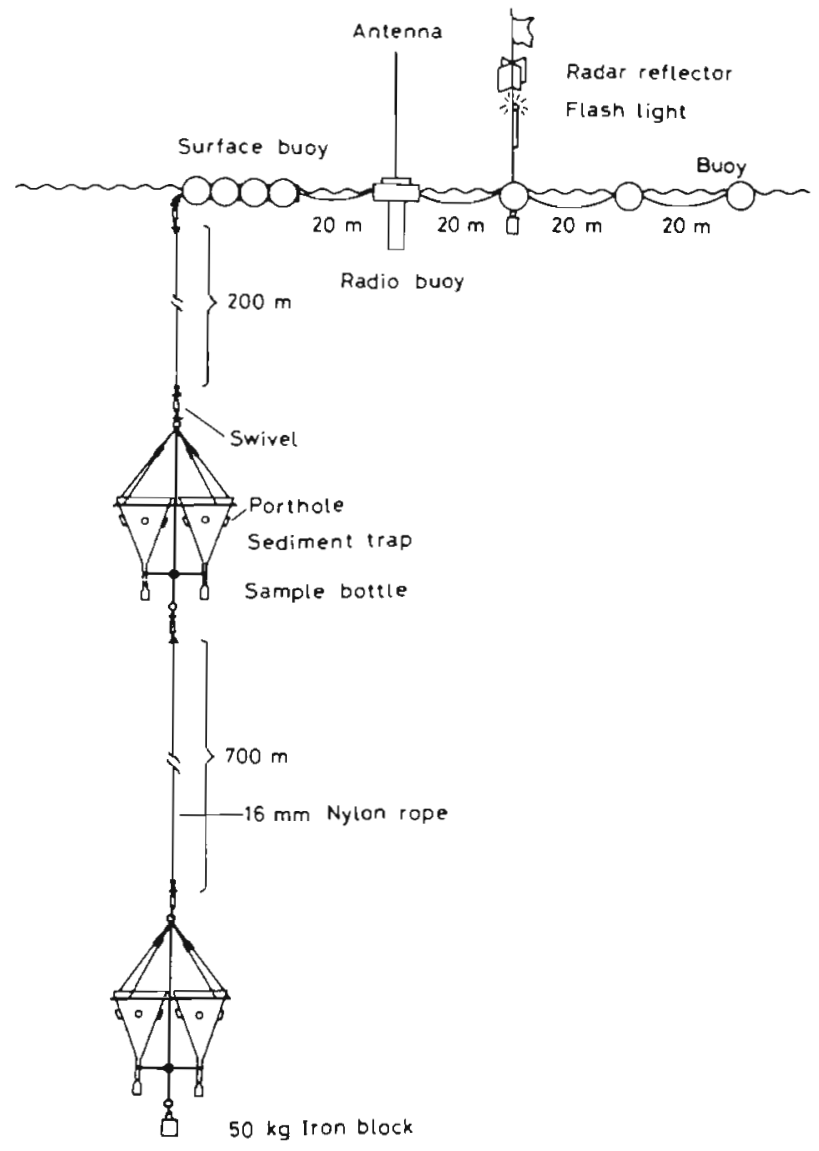

Fig. 1. Suspension system for sediment traps employed during the KH-74-2 cruise of R. V 'Hakuho-Maru' ammonium carbonate solution. The filter was dried at $60{ }^{\circ} \mathrm{C}$ for one night and then placed in a silica gel desiccator. After several hours of equilibration, the dry weight was measured. For POC determinations, an aliquot was filtered through pre-combusted $\left(500^{\circ} \mathrm{C}\right.$, $4 \mathrm{~h})$ Whatman GF/C glass-fiber filter and washed thoroughly with $3 \%$ sodium chloride solution to remove the formalin. The filter was dried at $60^{\circ} \mathrm{C}$ for one night. POC was then determined with a HitachiHoriba LIA-2 infra-red carbon analyzer (Strickland and Parsons, 1972).

Seawater was collected with 25 I Van Dorn bottles; 61 aliquots were immediately filtered by gentle suction through a double-layered, pre-combusted Whatman GF/C filter. The POC retained by two filters was determined separately employing the same procedures as described above. The value obtained for the second filter was substracted from that for the top filter (filter blank). Chlorophyll a was determined fluorometrically (Strickland and Parsons, 1972).

\section{RESULTS}

Figure 3 shows vertical profiles of temperature, salinity, oxygen, chlorophyll a and POC at Station 13. The POC tended to decrease rapidly with depth from the surface down to $100 \mathrm{~m}$, though there were two

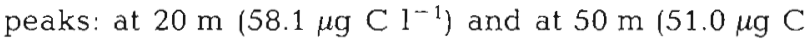
$\mathrm{I}^{-1}$ ). No further consistent decrease was evident below $100 \mathrm{~m}$.

Sedimented matter trapped in the formalin-treated bottle at $200 \mathrm{~m}$ was dominated by large dark-green particles (1-3 mm diameter), showing no sign of degra-

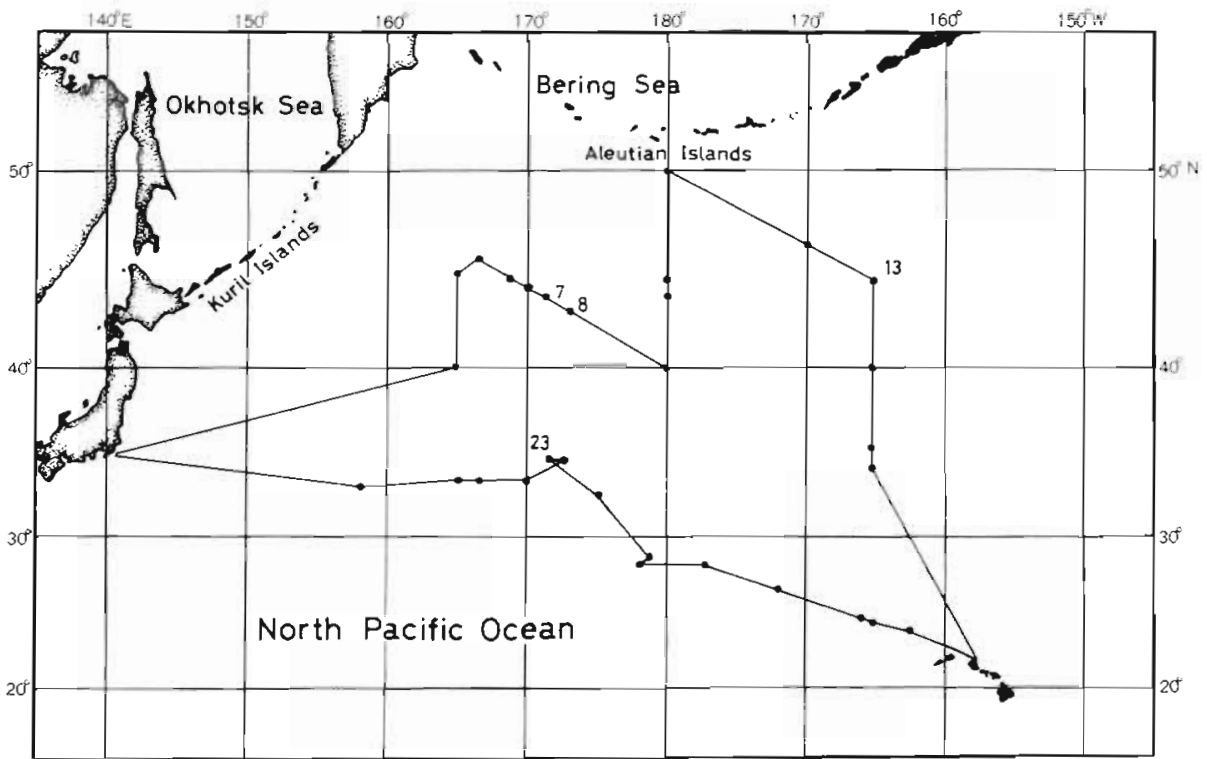

Fig. 2. Location of stations sampled during the KH-74-2 cruise of R. V. 'Hakuho-Maru', April 30-June 26, 1974 


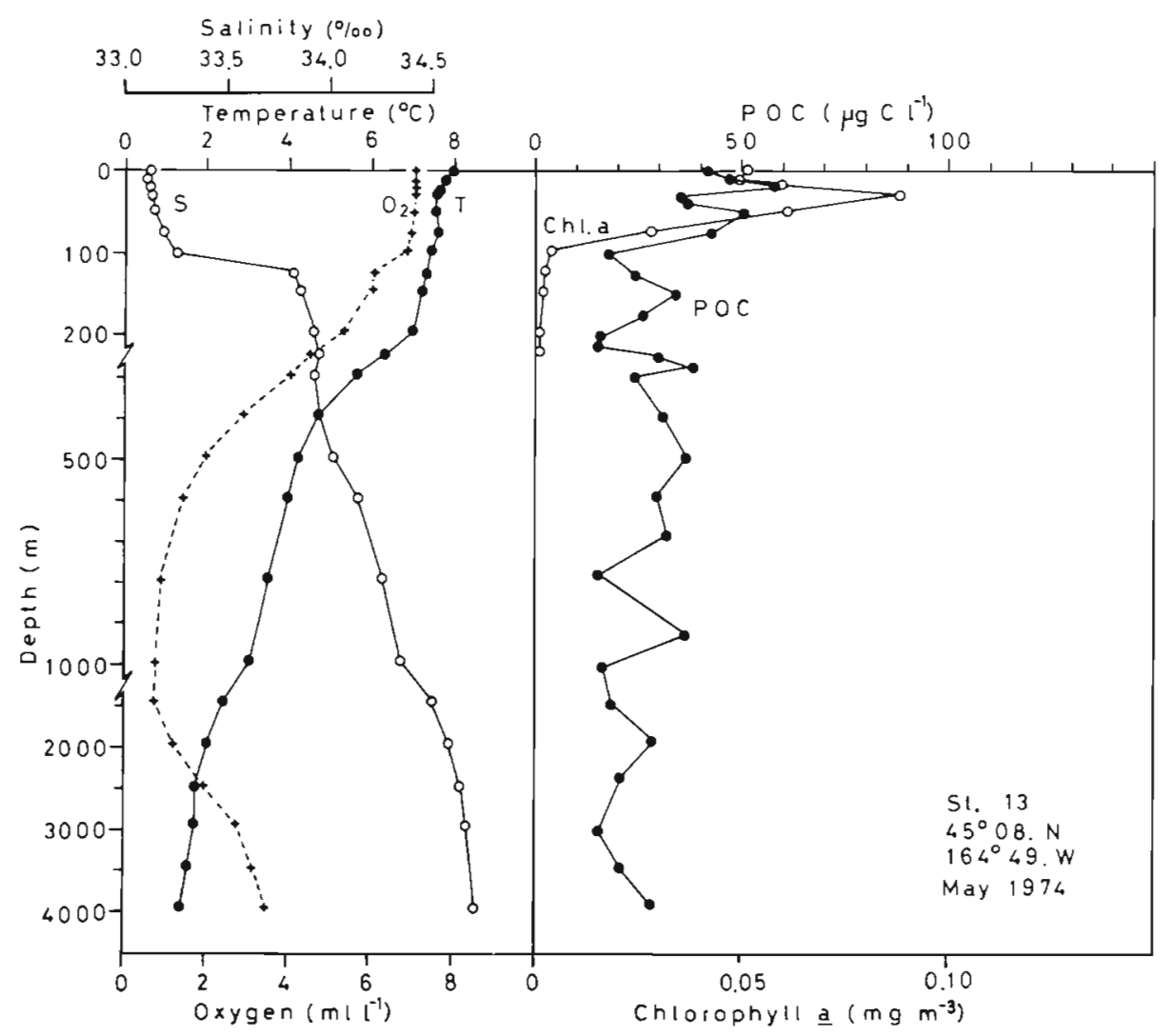

Fig. 3. Vertical profiles of temperature, salinity, dissolved oxygen, chlorophyll a and particulate organic carbon at Station 13

dation (Fig. 4A, B). On the other hand, particles obtained from the bottle without formalin were much smaller (Fig. 4C). In the latter case, 3 large copepods (Calanus cristatus) were swimming actively in the bottle.

Although large particles were also collected, most were much less consolidated at $900 \mathrm{~m}$ than at $200 \mathrm{~m}$ (Fig. 4D). It is likely that the particles sampled at both depths had the same origin. These particles were identical in color, shape and size with fecal pellets produced by salps. Salpa sp. were collected near Station 13 and produced fecal material on board (Fig. 4E). We have no quantitative data on the biomass of salps near Station 13 but we observed large numbers of salps at the surface at night. During the cruise salps and doliolids were often observed. In plankton tows at Stations 7,8 and 23, tunicates usually comprised more than $95 \%$ of the total zooplankton biomass (Taniguchi and Hirakawa, 1975). Salpa aspera predominated at Station 8 (N. Shiga, pers. comm.); at the remaining stations the species were not identified. S. maxima and $S$. fusiformis were also recorded in this area (Soest, 1974).

The dry weight and POC content of samples collected at $200 \mathrm{~m}$ were less in the bottles without formalin (Table 1). However, POC:dry weight ratios were similar in both samples $(0.16$ and 0.20$)$. In the formalintreated samples, both dry weight and POC were less at $900 \mathrm{~m}$. On the other hand, the POC:dry weight ratio increased from 0.16 to 0.26

The vertical flux of particulate matter was determined by dividing the amount of collected material by

Table 1 Dry weight, POC and POC: dry weight ratios of samples collected by sediment trap at Station 13 in the northern North Pacific Ocean

\begin{tabular}{|c|c|c|c|}
\hline $\begin{array}{l}\text { Depth } \\
(\mathrm{m})\end{array}$ & $\begin{array}{l}\text { Dry weight } \\
\left(\mathrm{mg} \text { bottle } e^{-1}\right)\end{array}$ & $\begin{array}{c}\text { POC } \\
\left(\mathrm{mgC} \text { bottle } e^{-1}\right)\end{array}$ & $\begin{array}{l}\text { POC : Dry } \\
\text { weight }\end{array}$ \\
\hline 200 & 22.2 & 3.57 & 0.16 \\
\hline $200^{\circ}$ & 11.5 & 2.34 & 0.20 \\
\hline $900^{\cdots}$ & 7.3 & 1.89 & 0.26 \\
\hline \multicolumn{4}{|c|}{$\begin{array}{l}\text { - Formalin-untreated bottle } \\
\text { Mean value of paired samples. Dry weight and POC } \\
\text { were measured after mixing of paired samples }\end{array}$} \\
\hline
\end{tabular}

the mouth area of the funnel $\left(0.25 \mathrm{~m}^{2}\right)$ and by the period of collection (1.21 d). Calculated fluxes were $60.0 \mathrm{mg}$ dry weight $\mathrm{m}^{-2} \mathrm{~d}^{-1}$ (or $10.5 \mathrm{mg} \mathrm{C} \mathrm{m}^{-2} \mathrm{~d}^{-1}$ ) at $200 \mathrm{~m}$, and $25.8 \mathrm{mg}$ dry weight $\mathrm{m}^{-2} \mathrm{~d}^{-1}$ (or $6.7 \mathrm{mg} \mathrm{C}$ $\mathrm{m}^{-2} \mathrm{~d}^{-1}$ ) at $900 \mathrm{~m}$. 

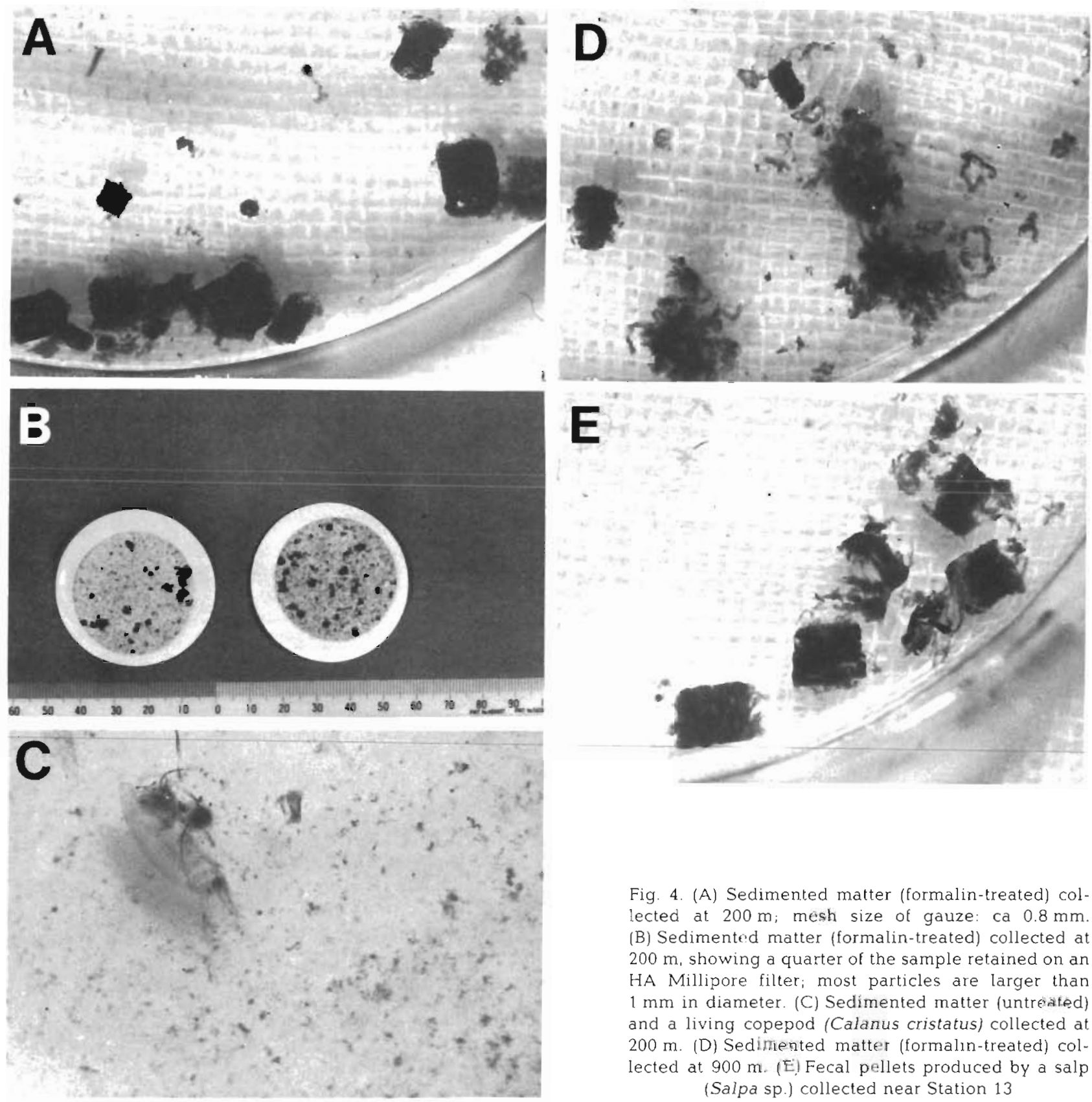

\section{DISCUSSION}

At $200 \mathrm{~m}$, fecal pellets in the sample bottle without formalin were largely disintegrated, and could not be positively identified as the fecal pellets of salps. Since the suspension period was not long enough for the pellets to be decomposed by bacterial attack, they might have been physically disintegrated by the active swimming and grazing of large copepods (Calanus cristatus) found in the bottle. Salp fecal peliets are soft and can easily be broken down into small fragments mechanically (Honjo, 1980).

In the formalin-untreated bottles dry weight and POC in sedimented matter were much lower than in the treated bottles, but the POC:dry weight ratio was not significantly different. Therefore, a major source of the difference may have been due to a different collecting efficiency of the funnels caused by inhomogeneous distribution of such large particles in sea water (orientation and 'shadow' effects of funnels); this may be a general problem inherent in the kind of experiment conducted (Spencer et al., 1978).

A somewhat higher POC:dry weight ratio was observed in sedimented matter from $900 \mathrm{~m}$ than from 
$200 \mathrm{~m}$. The association of bacteria and other microorganisms with the sedimented matter (probably at earlier stages of mineralization) may have been the cause for this higher ratio.

At night, Wiebe et al. (1979) observed a school of Salpa aspera, with an average density of 65 individuals $\mathrm{m}^{-3}$ in the upper $100 \mathrm{~m}$ in the North Atlantic Ocean, particularly concentrated in the upper $25 \mathrm{~m}$; during the day this massive population performed diel vertical migrations over $800 \mathrm{~m}$. The authors estimated that the vertical transport of dead salps was about $3.6 \mathrm{mg} \mathrm{C}$ $\mathrm{m}^{-2} \mathrm{~d}^{-1}$ (based on data of mortality and biomass). This amounts to about half of the daily food requirement of the benthic microfauna in the vicinity of the sampling site. Wiebe et al. further estimated fecal-pellet transport on the basis of average fecal-pellet production rates and night surface biomass. They reached the conclusion that from 8.5 to $137 \mathrm{mg} \mathrm{C} \mathrm{m} \mathrm{m}^{-2}$ could be transported daily to the deep sea. Even the minimum amount estimated would supply more than $100 \%$ of the daily metabolic needs of the deep benthic microfauna.

Our own observations yielded fluxes of 10.5 and $6.7 \mathrm{mg} \mathrm{C} \mathrm{m} \mathrm{m}^{-2} \mathrm{~d}^{-1}$ at 200 and $900 \mathrm{~m}$, respectively. This corresponds to the minimum estimate of Wiebe et al. (1979). Although these values are similar to those reported previously for various ocean areas (e.g. Wiebe et al., 1976; Iseki, 1977; Honjo, 1978, 1980; Iseki, 1981), the bulk of the material I collected was primarily composed of salp fecal material (Figs $4 A-D$ ). The flux decreased from 10.5 to $6.7 \mathrm{mg} \mathrm{C} \mathrm{m}^{-2} \mathrm{~d}^{-1}$ from $200 \mathrm{~m}$ to $900 \mathrm{~m}$, indicating possible decomposition during sedimentation through a water column of $700 \mathrm{~m}$ height. Below $900 \mathrm{~m}$, large particles-such as fecal pellets of salps-would, even though if disintegrating mechanically and microbiologically to some extent, reach the bathypelagic zone. In the north Central Pacific Ocean, Honjo (1980) evidently collected a salp fecal pellet in a trap set at $4,280 \mathrm{~m}$.

Several workers measured sinking rates of fecal pellets (natural and laboratory-produced by euphausiids and laboratory-produced by copepods) of 15 to $862 \mathrm{~m}$ $\mathrm{d}^{-1}$ (Smayda, 1969; Fowler and Small, 1972; Turner, 1977). Since fecal pellets of salps are much larger than those of copepods and euphausiids, their sinking rates are considered to be higher than several hundred meters per day. In fact, sinking rates of 196 to $445 \mathrm{~m}$ $\mathrm{d}^{-1}$ were recorded by $\mathrm{H}$. Sasaki (pers. comm.) for laboratory-produced fecal pellets of salps collected in the equatorial Pacific Ocean. Apart from contributing to the vertical flux of organic matter, salps also play an important role in accelerating the sedimentation of small particles, such as microflagellates and coccoliths which are too small to be consumed by most other herbivores. Through their unusual, highly efficient feeding mechanism, salps can finally transform small particles rapidly into large fecal pellets.

Regarding rapid vertical transport of particulate organic matter in the open sea, salp fecal pellets are considered to be of greater trophic importance than those of copepods and euphausiids. Salp swarms may thus provide considerable local enrichment to the deep-sea ecosystem.

Acknowledgements. I wish to offer my sincere thanks to Professor S. Nishizawa for encouraging me in this study. I would further like to thank Drs G. R. Harbison, D. J. Tranter, A. Taniguchi and $T$ Ikeda for critically reading my manuscript. I am grateful to Mr. K. Hirakawa for a photograph of salp fecal pellets. I thank Mr. N. Fujita for his kind help and finally, I acknowledge the kind cooperation of Professor $\mathrm{T}$. Kuroki and the scientists of the $\mathrm{KH}-74-2$ Cruise and of the officers and crew of the R. V. 'Hakuho-Maru'.

\section{LITERATURE CITED}

Berner, L. D. (1967). Distributional atlas of Thaliacea in the California Current region. Calcofi Atlas, No. 8 (California Marine Research Committee)

Bishop, J. K. B., Edmond, J. M., Ketten, D. R., Bacon, M. P., Silker, W. B. (1977). The chemistry, biology, and vertical flux of particulate matter from the upper $400 \mathrm{~m}$ of the equatorial Atlantic Ocean. Deep Sea Res. 24: 511-548

Brattström, H. (1972). On Salpa fusiformis Cuvier (Thaliacea) in Norwegian coastal and offshore waters. Sarsia 48: $71-90$

Fowler, S. W., Small, L. F. (1972). Sinking rates of euphausiid fecal pellets. Limnol. Oceanogr. 17: 293-296

Harbison, G. R., Gilmer, R. B. (1976). The feeding rates of the pelagic tunicate Pegea confederata and two other salps. Limnol. Oceanogr. 21: 517-528

Harbison, G. R., McAlister, V L. (1979). The filter-feeding rates and particle retention efficiencies of three species of Cyclosalpa (Tunicata, Thaliacea). Limnol. Oceanogr 24: 875-892

Honjo, S. (1978). Sedimentation of materials in the Sargasso Sea at a 5,367 m deep station. J. mar. Res. 36: 469-492

Honjo, S. (1980). Material fluxes and modes of sedimentation in the mesopelagic and bathypelagic zones. J. mar. Res. 38: $53-97$

Iseki. K. (1977). A study of vertical transport system of particulate organic matter in the sea. Ph. D. thesis, Tohoku University

Iseki, K. (1981). Vertical transport of particulate organic matter in the deep Bering Sea and Gulf of Alaska. J. oceanogr Soc. Japan (in press)

Madin, L. P. (1974). Field observations on the feeding behavior of salps (Tunicata: Thaliacea). Mar. Biol. 24: 143-147

McCave, I. N. (1975). Vertical flux of particles in the ocean. Deep Sea Res. 22: 491-502

Smayda, T. J. (1969). Some measurements of the sinking rate of fecal pellets. Limnol. Oceanogr. 14: 621-625

Soest, R. W. M. van. (1974). A revision of the genera Salpa Forskal, 1775, Pegea Savigny, 1816, and Ritteriella Metcalf, 1919 (Tunicata, Thaliacea). Beaufortia 22: 153-191

Spencer, D. W., Brewer, P. G., Fleer, A., Honjo, S., Krishnaswami, S., Nozaki, Y (1978). Chemical fluxes from a sediment trap experiment. J. mar. Res. 36: 493-523 
Strickland, J. D. H., Parsons, T. R. (1972). A practical handbook of seawater analysis (2nd ed.). Bull. Fish. Res. Bd Can. 167: 1-311

Taniguchi, A., Hirakawa, K. (1975). Microplankton communities. In: Kuroki, T. (ed.) Preliminary report of the Hakuho-Maru Cruise $\mathrm{KH}-74-2$, Ocean Research Institute, University of Tokyo, pp. 20-22

Turner, J. T (1977). Sinking rates of fecal pellets from the marine copopod Pontella meadii. Mar. Biol. 40: 249-259
Wiebe, P. H., Boyd, S. H., Winget, C. (1976). Particulate matter sinking to the deep-sea floor at $2,000 \mathrm{~m}$ in the Tongue of the Ocean, Bahamas with a description of a new sedimentation trap. J. mar. Res. 34: 341-354

Wiebe, P. H., Madin, L. P., Haury, L. R., Harbison, G. R. Philbin, L. M. (1979). Diel vertical migration by Salpa aspera and its potential for large scale particulate organic matter transport to the deep-sea. Mar. Biol. 53: 249-255

This paper was presented by Professor M. Anraku; it was accepted for printing on December 30, 1980 